Vesna Rastija

Kristina Mihaljević

Mato Drenjančević

Vladimir Jukić
UDK: 663.2(497.5)

DOI: http://doi.org/10.21857/yrvgqtpxw9

Izvorni znanstveni članak

Rukopis prihvaćen za tisak: 14.9.2016.

\title{
KORIŠTENJE SAZNANJA O POLIFENOLNOM PROFILU HRVATSKIH VINA U MARKETINŠKE SVRHE
}

\begin{abstract}
Sažetak
Umjerena i redovita konzumacija vina povezana je s brojnim blagotvornim učincima vina na zdravlje čovjeka. Ti učinci su povezani s polifenolnim supstancijama iz vina koje imaju najsnažniji utjecaj na bolesti srca i krvnih žila. Polifenolne sastavnice vina su također zaslužne za antikancerogeno, neuroprotektivno i antidijabetičko djelovanje. Na temelju toga vino se, posebice crno, može smatrati funkcionalnom hranom koja ima i dokazano farmakološko djelovanje. Hrvatska obiluje vinorodnim područjima i kvalitetnim vinima, ali su te činjenice slabo iskorištene u marketinške svrhe.

Crna vina iz Srednje i Južne Dalmacije imaju najveći sadržaj polifenola, što se pripisuje povoljnijim klimatskim uvjetima koji uvelike utječu na formiranje tih tvari u grožđu tijekom zriobe. Međutim, neka vina iz kontinentalne Hrvatske svojom kvalitetom ne zaostaju za dalmatinskim vinima. Naša se vina moraju istaknuti iz mase stranih, uvoznih vina koja su mahom jeftinija, ali ne nužno i slabije kvalitete od hrvatskih te privući kupca i u našoj zemlji, a posebice $\mathrm{u}$ inozemstvu. Navedene činjenice treba maksimalno iskoristiti u strategiji prodaje, distribucije, promocije i marketinga hrvatskih vina.
\end{abstract}

Ključne riječi: polifenoli; hrvatska vina; funkcionalna hrana; marketing.

\section{Uvod}

Na tlu Hrvatske vinova loza (Vitis vinifeta, L.) našla je izvanredno pogodno podneblje, klimu, konfiguraciju i sastav tla. Uzgoj vinove loze i vinarstvo ima bogatu i dugu povijest na prostorima današnje Hrvatske. Tijekom razdoblja grčke kolonizacije, uzgoj vinove loze i proizvodnja vina postaje vrlo bitan čimbenik gospodarstva na otocima i obalnom dijelu Jadrana, a grožđe i vino važni tržišni proizvodi. Dolaskom Rimljana započinje ponovna obnova i procvat vinogradarstva i vinarstva na području Dalmacije, Istre i unutrašnjosti tadašnje rimske Panonije. Nakon dolaska u novu domovinu, Hrvati preuzimaju znanja o vinogradarenju i proizvodnji vina od 
starosjedilačkih romaniziranih ilirskih plemena. U srednjem vijeku kršćanski redovnici, posebice benediktinci, promicali su vinogradarstvo i vinarstvo, a komunalni statuti hrvatskih srednjovjekovnih gradova propisuju načine vinogradarenja, proizvodnje i trženja vina. Nakon turske vladavine, tijekom 18. stoljeća, slijedi uspon vinogradarstva i vinarstva, posebice u Slavoniji, gdje se utemeljuju veliki plemićki posjedi i obnavljaju vinogradi. Godine 1996. Hrvatska dobiva vlastiti Zakon o vinu, a kasnije i podzakonske propise čime je vinima proizvedenim u Hrvatskoj omogućeno jamstvo autentičnosti i originalnosti podrijetla i kakvoće. U Hrvatskoj se trenutno uzgaja 197 kultivara vinove loze (Herjavec i sur., 2002).

Polifenoli čine skupinu organskih molekula biljnog podrijetla koji posjeduju aromatski prsten s jednom ili više hidroksilnih skupina. Polifenolne supstancije, koje se nalaze u kožici, sjemenkama i mesu bobica te peteljkama grožđa, izlučuju se u vino tijekom procesa vinifikacije. Od izuzetne su važnosti za kvalitetu vina jer utječu na razne osobine vina, primjerice na boju, oporost, gorčinu, stupanj oksidacije i bistroću (Burns i sur., 2001).

Polifenoli iz kožice, sjemenki i usplođa crnog grožđa ekstrahiraju se u crno vino tijekom procesa vinifikacije. Sastav i količina pojedinih polifenola ovisi o sorti grožđa, klimatskim uvjetima, postupcima uzgoja vinove loze i primijenjenim metodama izrade vina (Landrault i sur., 2001; Zafrilla i sur., 2003).

Posljednjih dvadesetak godina mnoga istraživanja pokazala su da namirnice koje sadrže polifenole pozitivno utječu na zdravlje i to najvećim dijelom zbog antioksidacijskog učinka tih sastavnica. Vina, posebice crna, sadrže u velikoj količini polifenolne supstancije (1000 mg L-1 do $1300 \mathrm{mg} \mathrm{L}^{-1}$ ), koje pokazuju brojne biološke učinke. Mnoga istraživanja su pokazala kako antioksidacijsko djelovanje ovih supstancija u vinu štiti od nastanka ateroskleroze i koronarnih bolesti, stoga se smatra da redovita i umjerena konzumacija vina smanjuje mogućnost obolijevanja od tih bolesti. Osim toga dokazano je njihovo antikancerogeno, protuupalno i antimikrobno djelovanje (Rastija, 2011).

Iako je u Hrvatskoj razvijeno vinarstvo te Hrvatska kao takva obiluje vinorodnim područjima i kvalitetnim vinima, analiza polifenola u vinima iz Hrvatske je rijetka, a polifenolni sastav u hrvatskim vinima slabo iskorišten u marketinške svrhe.

Cilj ovog rada upoznavanje je s vrijednim svojstvima i kvalitetom hrvatskih vina te primjene tih saznanja u formiranje marketinške strategije.

\section{POLIFENOLI}

Polifenoli su razvrstani u tri osnovne skupine: fenolne kiseline, flavonoidi i stilbeni. Strukturne formule najčešće prisutnih polifenola u vinu prikazane su na slici 1.

Najjednostavniji polifenoli su fenolne kiseline koje posjeduju jedno zajedničko strukturno obilježje, aromatski prsten koji ima najmanje jednu hidroksilnu skupi- 
nu. Razlikujemo dvije skupine fenolnih kiselina: derivate hidroksibenzojeve kiseline (vanilinsku, siringinska, galnu, $m$-hidroksibenzojevu, $p$-hidroksibenzojevu i gentizinsku kiselinu) i derivate hidroksicimetne kiseline (o-kumarinsku, $p$-kumarinsku, ferulinska, kafeinska i klorogensku kiselinu). Tijekom fermentacije i starenja vina, hidroksicimetne i hidroksibenzojeve kiseline mijenjaju svoje oblike i sadržaj. Ovi spojevi sudjeluju u formiranju žutih ili smeđih pigmenata koji utječu na kvalitetu bijelih vina (Budić-Leto i sur., 2002).

Aglikoni flavonoida (flavonoidi bez vezanih molekula šećera) posjeduju strukturu tipa $\mathrm{C}_{6}-\mathrm{C}_{3}-\mathrm{C}_{6}$, odnosno sadrže petnaest atoma ugljika raspoređenih tako da su dvije benzenske jezgre povezane s propanskim lancem koji može ili ne mora formirati treći prsten. U vinu su prisutne sljedeće skupine flavonoida: flavoni (apigenin); flavonoli (kvercetin, kemferol, miricetin), flavanoni (naringenin); flavanoli ili katehini (katehin, epikatehin); proantocijanidini ili kondenzirani tanini (procijanidin B1, procijanidin B2); antocijanidini (pelargonidin, cianidin, delfinidin, peonidin, petunidin, malvidin); izoflavonoidi (genistein).

U prirodi su flavonoidi većinom vezani s molekulama šećera, čineći glikozide u kojima je jedna ili više hidroksilnih skupina flavonoida vezana na molekulu, odnosno molekule šećera. Glikozidi flavonoida manje su reaktivni, polarniji su, te su stoga topljiviji u vodi od odgovarajućih aglikona, što je neophodno za njihovo pohranjivanje $\mathrm{u}$ biljnim vakuolama gdje se obično nalaze.

Stilbeni su neflavonoidini polifenoli koji sadrže 1,2-difenileten kao funkcionalnu skupinu. Najpoznatiji predstavnik ove skupine polifenola je resveratrol (Markham, 1982).

\section{Polifenoli u vinu}

Polifenolne supstancije koje se nalaze u kožici, sjemenkama i mesu bobica te peteljkama grožđa izlučuju se $\mathrm{u}$ vino tijekom procesa vinifikacije. Također, polifenoli nastaju kao metaboliti kvaščevih gljivica u procesu vrenja i starenja vina.

Mnogi čimbenici utječu na sastav i sadržaj polifenola u vinu. Jedan od najvažnijih čimbenika vrsta je vina i sorti grožđa od kojeg je napravljeno. Najzastupljeniji su u crnim vinima (1000 mg L-1 do $\left.4000 \mathrm{mg} \mathrm{L}^{-1}\right)$, dok je za bijela vina (200 mg L-1 do 300 $\mathrm{mg} \mathrm{L}^{-1}$ ) karakterističan manji sadržaj tih supstancija (Landrault i sur., 2001).

Postupak uzgoja vinove loze poput uklanjanja listova povećava osunčanosti grozdova, a time i povećanu biosintezu polifenola (Nicolosi i sur., 2012). Uklanjanje grozdova utječe na smanjenja priroda, ali povećava kvalitetu grožđa (Gil i sur., 2013). Prikladnom i ne pretjeranom gnojidbom, moguće je utjecati na sadržaj polifenola. Također je dokazano da dušična gnojiva, za razliku od kalijevih, smanjuju nakupljanje polifenola u kožici grožđa (Delagado i sur., 2004). 
FENOLNE KISELINE<smiles>O=C(O)c1cc(O)c(O)c(O)c1</smiles>

galna kiselina

$\mathrm{HOOC}$<smiles>C/C=C/c1ccc(O)c(O)c1</smiles><smiles>O=C(O)c1ccc(O)cc1</smiles>

p-hidroksibenzojeva kiselina

HOOC<smiles>C/C=C/c1ccc(O)cc1</smiles>

Hidroksicimetne kiseline

\section{FLAVONOIDI}<smiles>c1ccc(C2CCc3ccccc3O2)cc1</smiles>

osnovna struktura flavonoida<smiles>O=c1c(O)c(-c2ccc(O)c(O)c2)oc2cc(O)cc(O)c12</smiles>

kvercetin (flavonol)<smiles>O=c1cc(-c2ccc(O)cc2)oc2cc(O)cc(O)c12</smiles>

apigenin (flavon) naringenin (flavanon)

STILBENI<smiles>Oc1ccc(/C=C/c2cc(O)cc(O)c2)cc1</smiles>

resveratrol

Slika 1. Strukturne formule najvažnijih polifenola prisutnih u vinu. 
Vinogradski uvjeti poput vrste tla, klime, i bolesti tijekom uzgoja, utječu na sastav polifenola u grožđu (McDonald i sur., 1998). Tako je jedan od važnih čimbenika i položaj vinograda. Primjerice, veća količina antocijanina nađena je u kožici grožđa uzgojenih u vinogradima smještenim na većim nadmorskim visinama, dok je grožđe uzgojeno na nižim nadmorskim visinama sadržavalo veću količinu procijanidina (Mateus i sur., 2001). Dobro osunčani položaji, smješteni u relativno suhoj klimi, rezultiraju većim sadržajem polifenola (Bergqvist i sur., 2001).

Kvaliteta grožđa također je izuzetno važan čimbenik u određivanju sadržaja polifenola u vinu. Kvalitetnije grožđe ima manje grozdove koji sadrže veći udio kožice u odnosu na manje kvalitetno grožđe koje ima mesnatije i veće bobice. Vino proizvedeno od kvalitetnijeg grožđa tako sadrži veću količinu polifenola izlučenih iz kožice (Burns i sur., 2001). Pretjerano veliki urod i bolesti vinove loze smanjuju kvalitetu grožđa, a time i količinu polifenola (Weston, 2000).

Fenolne kiseline u crnim sortama grožđa najzastupljenije su u kožici, a u bijelim sortama u mesu bobice. Tijekom fermentacije i starenja vina dolazi do brojnih reakcija u kojima hidroksibenzojeve i hidroksicimetne kiseline mijenjaju svoje oblike i sadržaje. Smatra se da su fenolne kiseline mogući uzrok nestabilnosti vina, jer sudjeluju u stvaranju taloga ili su uključene u proces posmeđivanja vina (Budić-Leto i sur., 2002). Međutim, fenolne kiseline iz vina imaju pozitivan učinak na zdravlje čovjeka, s obzirom da im je dokazan antioksidativni i vazodilatacijski efekt (Mudnic i sur., 2010).

Flavoni i flavonoli koje nalazimo u vinu od izuzetne su biološke važnosti jer djeluju kao antioksidansi i hvatači slobodnih radikala. Do danas je raznim kromatografskim metodama otkriven čitav niz aglikona flavona (apigenin, luteolin) i flavonola (kvercetin, kemferol, miricetin, galangin, izoramnetin) u vinu (Kallithraka i sur., 2006; Rastija i sur., 2009). Količina flavonola u bijelim vinima je vrlo mala, što je i za očekivati jer su te supstancije najviše zastupljene u kožici grožđa koja se najčešće ne upotrebljava u proizvodnji bijelog vina.

Od flavanona $\mathrm{u}$ vinu su najzastupljeniji naringenin $\mathrm{i}$ hesperetin $\mathrm{u}$ tragovima. Oba flavanona djeluju protuupalno te utječu na metabolizam masti i spolnih hormona (Erlund, 2004).

Flavanoli i proantocijanidini su fenolne supstancije koje se uglavnom nalaze u sjemenkama i kožici grožđa i ekstrahiraju se u vino tijekom fermentacije i maceracije, tako da na sadržaj tih supstancija u vinu u najvećoj mjeri utječe tehnološki postupak proizvodnje vina. Za razliku od bijelih vina, znatno veći sadržaj katehina i epikatehina nalazi se u crnim vinima, a velika je i razlika između vina proizvedenih iz različitih kultivara vinove loze. Osim što navedene supstancije utječu na boju, miris, oporost, gorčinu, stupanj oksidacije i bistroću vina, poznata je i njihova biološka aktivnost, naime oni djeluju protuupalno, antikancerogeno i antimutageno (Revilla i González-SanJosé, 2003, Katalinić, 1997, Ćurko i sur., 2014). 
Boja crnih i ružičastih vina potječe od antocijanina. Monomerni oblici antocijanina ekstrahiraju se u vino tijekom runjanja i muljanja grožđa, tiještenja masulja i fermentacije, a mladim vinima daju purpurno crvenu boju. Tijekom starenja vina dolazi do formiranja polimernih antocijanina ili tanina stvaranjem kovalentnih veza između monomernih antocijanina. Antocijanini se istovremeno vežu s drugim polifenolima (posebice s flavanolima i procijanidinima) i reagiraju s neflavonoidnim supstancijama, kao što su acetaldehid i pirogrožđana kiselina. Svi ti procesi rezultiraju stabilizacijom boje crnog vina koja se mijenja u ciglastocrvenu boju (Gutiérrez i sur., 2005). Starenjem vina povećava se njegova antioksidacijska aktivnost uslijed postepenog povećanja količine tanina nastalih polimerizacijom antocijanina (Burns i sur., 2001).

Resveratrol je u velikoj količini prisutan u kožici grožđa, posebice crnog, stoga se u bitnoj količini nalazi u crnim vinima te puno manjoj u bijelim i ružičastim vinima. U vinima su prisutni i cis- i trans- izomeri resveratrola, ali u različitim omjerima koncentracija, što uveliko ovisi o kultivaru vinove loze. Osim toga, važni čimbenici, osim sorte vinove loze, su duljina kontakta kožice tijekom fermentacije, stupanj maceracije kožice te ostali enološki postupci nakon fermentacije vina, primjerice, način pročišćavanja i bistrenja vina prije punjenja u boce. Objavljeni su brojni radovi o biološkim učincima resveratrola. Poznato je da resveratrol sudjeluje u zaštiti od bolesti srca i krvnih žila te da posjeduje antioksidacijska, protuupalna, neuroprotektivna i antikancerogena svojstva (Katalinić i sur., 2008).

\section{Pozitivni učinci polifenola iz vina na zdravlje čovjeka}

Antioksidacijska aktivnost vina i utjecaj polifenola iz vina na bolesti srca i krvnih žila

Godine 1992. objavljeni su rezultati epidemoloških istraživanja Reanuda i deLorgerila (1992) u kojima je opažena vrlo mala smrtnost od srčanih bolesti, premda tamošnje stanovništvo konzumira hranu bogatu mastima. Ta mala zastupljenost srčanih bolesti kod Francuza, koja se objašnjava redovitom umjerenom konzumacijom crnog vina, naziva se francuski paradoks. Dokazano je da crno vino zajedno s prisutnim polifenolima velike antioksidacijske aktivnosti povećava antioksidacijski kapacitet seruma, inhibira nakupljanje trombocita i pokazuje sposobnost hvatanja slobodnih radikala. Resveratrol posjeduje najveću sposobnost inhibicije oksidacije LDL-a te blokira nakupljanje trombocita u krvnim žilama i sprječava stvaranje krvnih ugrušaka. Također je dokazano da ekstrakti polifenola iz crnog vina, s i bez prisustva etanola, djeluju preventivno na srčanu hipertenziju. Sprječavanje nastanka visokog krvnog tlaka polifenolima povezano je s prevencijom disfunkcije endotela krvnih žila te svojstvom polifenola da opuštaju krvne žile (AlAwwadi i sur., 2004, Ou i sur., 2006). In vivo istraživanjima na štakorima dokazano 
je da trans-resveratrol ima svojstvo sprječavanja rasta sistoličkog krvnog tlaka te sprječavanja razvoja srčane hipertrofije (Liu i sur., 2005).

\section{Hormonska aktivnost}

Najpoznatija skupina flavonoida prisutnih $u$ vinu koja posjeduje estrogenska svojstva su izoflavonoidi, najviše istraživanja rađeno je s genisteinom. Također su dokazana i estrogenska svojstva resveratrola (Gehm i sur., 2004.; Monteiro i sur., 2008).

\section{Utjecaj polifenola iz vina na zloćudne tumore}

Brojna istraživanja dokazala su da su polifenoli jedni od obećavajućih antitumorskih prirodnih supstancija. Inhibicija rasta tumorskih stanica polifenolnim supstancijama je opažena u eksperimentima na životinjama oboljelim od tumora i na stanicama humanih tumora. Rađene su brojne studije kojima su dokazana antitumorska djelovanja nekih polifenola iz vina. Dokazano je da galna kiselina, katehin, trans-resveratrol i kvercetin inhibiraju karcinogenezu bilo da su eksperimenti rađeni in vitro na linijama stanica ili in vivo na životinjama ili ljudima oboljelim od zloćudnih tumora. Kvercetin inhibira rast zloćudnih stanica želuca, crijeva i kože. Katehin i trans-resveratrol zaustavljaju rast zloćudnih stanica prostate i dojke, dok je za galnu kiselinu dokazano da pokazuje antitumorska svojstava kod tumora pluća, želuca, crijeva i leukemije. Pošto je relativna koncentracija trans-resveratrola najveća od spomenutih supstancija i da se on najbolje apsorbira kod ljudi nakon kozumacije vina, smatra se da je ta supstancija najučinkovitija glede antitumorskih svojstava (He i sur., 2008; Soleas i sur., 2002).

\section{Protuupalno djelovanje}

Dokazano je da polifenoli inhibiraju prostanglandine koji tijekom upalnog procesa uzrokuju osjet boli, povišenje temperature i nastajanje edema. Dokazano je da su resveratrol, katehin i epikatehin inaktivatori prostanglandine koja također sudjeluje u procesu nastajanja krvnog ugruška (Szewczuk i Penning, 2004). Liofilizirani ekstrakti vina koji su u velikoj koncentraciji sadržavali antocijane, proantocijanidine i derivate hidroksicimetne kiseline pokazali su veće protuupalno djelovanje od nesteroidnog lijeka indometacina (Panico i sur., 2006).

\section{Antimikrobno djelovanje}

Brojna istraživanja dokazala su antimikrobni učinak pojedinačnih polifenola protiv bakterija, protozoa i gljivica. Također je dokazano antimikrobno djelovanje ekstrakata kožice grožđa i crnog vina protiv brojnih bakterija kao što su: Staphylococcus aureus, Bacillus cereus, Escherichia coli, Salmonella infantis, Campylobacter coli, Heli- 
cobacter pylori i Lysteria monoxytogenes. Također su pokazali djelovanje protiv gljivice Candida albicans (Rastija, 2011).

\section{Antidijabetički učinak}

Dokazano je da ekstrakti polifenola iz crnog vina reduciraju glikemiju, utječu na smanjenje unosa hrane i tjelesne težine životinja oboljelih od dijabetesa. Polifenoli također smanjuju koncentraciju masnih kiselina i triglicerida u krvi inhibicijom enzima fosfodiesteraze u stanju hipoglikemije (Chuang i sur., 2011).

\section{Neuroprotektiono djelovanje}

Suvremene studije pokazuju da umjereno konzumiranje crnog vina smanjuje rizik od nastanka Alzheimerove bolesti, smanjenja kognitivnih funkcija i nastanka demencije. Polifenoli iz vina prema navedenim studijama sprječavaju nastanak reaktivnog kisika, čija je akumulacija ključna za smrtonosne procese starenja mozga i promjene aktivnosti intracelularnih signalnih molekula (Martin i sur., 2011; Gao i Hu, 2005).

\section{Ostali pozitioni učinci}

Polifenoli iz vina djeluju preventivno na razvoj očne mrene i makularne degeneracije (King i sur., 2005, Russo i sur., 2003). Crno vino inhibira razvoj bakterije Streprococcus mutans koja se nalazi u zubnom plaku i uzrokuje karijes (Daglia i sur., 2010).

\section{Sadržaj polifenola u hrvatskim vinima}

Provedeno je istraživanje sadržaja ukupnih polifenola u uzorcima vina iz tri vinogradarske podregije Hrvatske. Najveći sadržaj ukupnih polifenola sadržavala su tri crna vina iz vinogradske podregije Srednja i Južna Dalmacija (1797,718 mg L-1), a zatim slijede vina iz Slavonije i Podunavlja $\left(1151,609 \mathrm{mg} \mathrm{L}^{-1}\right)$, dok vina iz Istre imaju najmanji sadržaj ukupnih polifenola $\left(1097,817 \mathrm{mg} \mathrm{L}^{-1}\right)$ (Rastija i sur,. 2009). Veliki sadržaj polifenola u vinima iz Srednje i Južne Dalmacije uvjetovan je geografskim položajem i klimom koja je pogodna za pojačanu biosintezu polifenola u grožđu. Od ispitivanih vina najveći sadržaj ukupnih polifenola određen je u vinu Plavac s Hvara (Slika 2). Sadržaj ukupnih polifenola u bijelim vinima je bitno manji od onih u crnim vinima. Razlog tako malog sadržaja polifenola u bijelim vinima manjak je antocijanina i drugih pigmenata koje sadrže crna vina, a ekstrahiraju se iz kožice i sjemenki tijekom fermentacije u sok. Naime, kožice i sjemenke odvajaju se od soka u postupku pravljenja bijelog vina, a kod crnog vina odvajaju se tek nakon određenog stupnja fermentacije. 


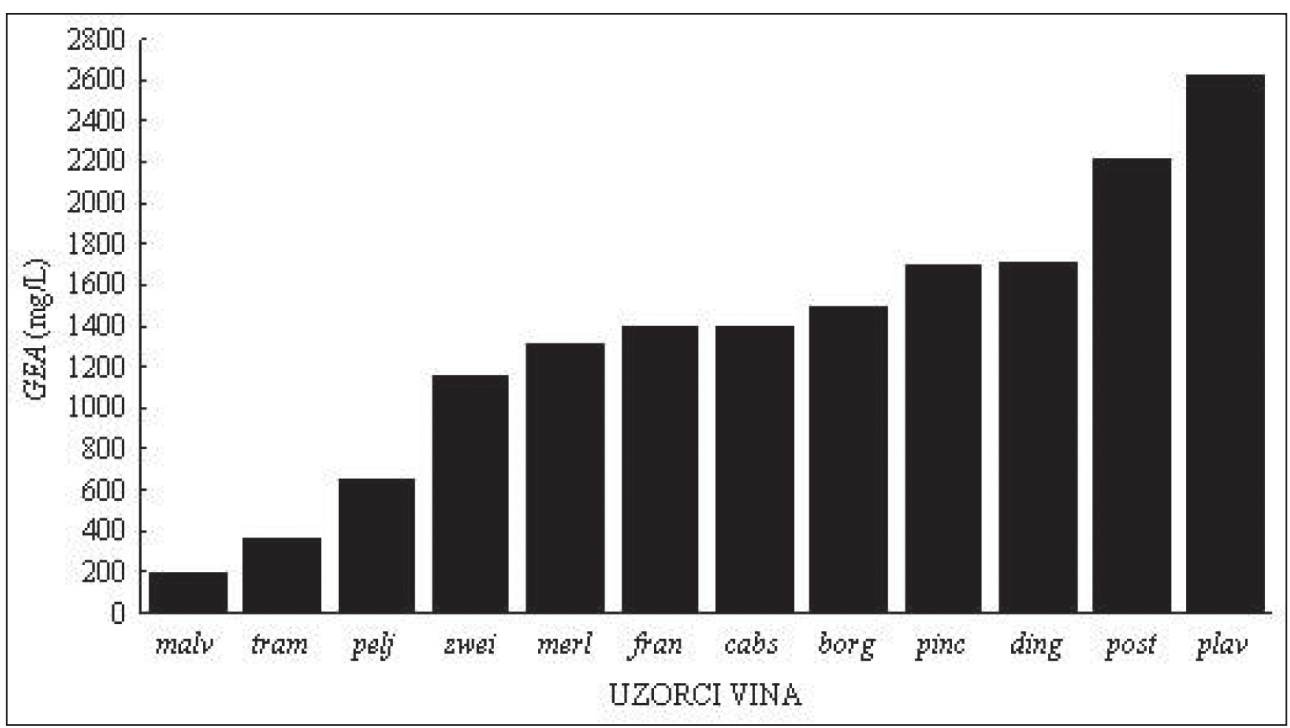

Slika 2. Grafički prikaz sadržaja ukupnih polifenola u pojedinim uzorcima vina (Frankovka, fran; Pinot crni, pinc; Traminac, tram; Zweigelt, zwei; Postup, post; Plavac, plav; Pelješac, pelj;

Dingač, ding; Merlot, merl; Borgonja, borg; Malvazija, malv; Cabernet Sauvignon, cabs).

(Rastija i sur,. 2009).

Kromatografskim istraživanjem pojedinačnih polifenola određena je najviša koncentracija galne kiseline u "Plavcu" (26,9 mg L-1). Najzastupljenija skupina flavonoli (kemferol, miricetin i kvercetin) najzastupljeniji su u vinima iz Srednje i Južne Dalmacije i Istre, dok su u vinima iz Slavonije i Podunavlja njihove koncentracije vrlo niske. Naime, na masenu koncentraciju flavonola u vinu uveliko utječu klimatski uvjeti. Iz ranijih istraživanja je poznato da na sadržaj flavonola u grožđu utječe količina sunčevih zraka tijekom dozrijevanja (Fang i sur., 2007). Stoga je razumljivo da su vina iz Primorske Hrvatske bogatija flavonolima. Velika različitost u koncentraciji flavonola u različitim uzorcima vina uvjetovana je ne samo različitim klimatskim uvjetima, već i metodama vinifikacije i proizvodnje vina. U bijelim vinima sadržaj flavonola je vrlo mali jer se te supstancije nalaze u kožici grožđa koja se ne koristi u proizvodnji bijelih vina. Iznimka je bijelo vino iz južne Dalmacije „Pelješac" koji je prema ukupnoj masenoj koncentraciji flavonola $\left(4,5 \mathrm{mg} \mathrm{L}^{-1}\right)$ približan kakvoći crnih vina. U radu Šeruga i suradnika (2011), osim najvećeg sadržaja polifenola u vinima iz Dalmacije, tim vinima je određena i najjača antioksidacijska aktivnost.

Dobiveni rezultati govore u prilog kvaliteti vina iz Hrvatske koja ne zaostaje sa svjetski poznatim vinima. Povoljni klimatski uvjeti i tradicionalni postupci uzgoja vinove loze i proizvodnje vina stvaraju uvjete za proizvodnju vrhunskih vina. Ia- 
ko su vina iz podregije Srednje i Južne Dalmacije zbog odlične osunčanosti, povoljnog tla i topline u najvažnije vrijeme - kad sazrijeva grožđe, idealna za proizvodnju vrhunskih vina bogatih antioksidansima, vina iz drugih područja Hrvatske također imaju dostatnu količinu polifenola te bi njihova umjerena i redovita konzumacija učinkovito štitila od nastanka nekih bolesti. Na temelju tih saznanja trebala bi se temeljiti marketinška strategija tih vina u cilju što uspješnijeg plasiranja na domaće i inozemno tržište.

\section{MARKETING I PROMOCIJA HRVATSKIH VINA TEMELJEM POLIFENOLNOG SASTAVA}

\section{Sadašnji marketing vina u Hrvatskoj}

Hrvatska je vinska zemlja, loza se ovdje uzgaja tisućama godinama kao dio poljoprivredne tradicije gotovo svih regija. Pojedina hrvatska vina svojom su kvalitetom konkurentna i na razini visokokvalitetnih svjetskih vina. Hrvatsko tržište zasićeno je velikim brojem raznih vina iz svih krajeva svijeta, a potrošnja ne raste s proizvodnjom. Uvozna vina su jeftina i približno iste kvalitete kao i hrvatska. U Hrvatsku se godišnje uvozi oko 15 milijuna litara vina, a izvozi 3 milijuna. Tržište zapadne Europe zasićeno je vinima iz cijelog svijeta koja mogu našim vinima konkurirati i kvalitetom i cijenom. Vina iz Hrvatske, iako kvalitetna, ujedno su i skupa te je zbog previsoke cijene mogućnost prodaje naših vina u velikim robnim kućama mala. Rješenje možda leži u drugim organiziranim kanalima prodaje poput internetske prodaje ili specijaliziranih vinoteka. Uz pokušaje proboja na strana tržišta, vrlo je važan stalan i uporan rad na popularizaciji hrvatskih vina među stranim potrošačima. Iako je zadnjih godina sama tehnologija proizvodnje dignuta na puno višu razinu isto se nije dogodilo s marketingom i stvaranjem prepoznatljivog imidža hrvatskih vina. Uz svako vino trebalo bi utkati priču vezanu za povijest, karakteristike regije, tradiciju i gastronomiju. U smislu organiziranog djelovanja najviše su napredovali vinari Istre udruženo djelujući preko udruge Vinistra. Istoimena godišnja izložba vina odličan je primjer kako predstaviti vrhunski proizvod potencijalnim potrošačima.

\section{Marketing i promocija vina iz Hrvatske na temelju polifenolnog sastava}

Marketinška strategija predstavlja dugoročne marketinške ciljeve na ciljnom tržištu te odabir odgovarajućeg marketinškog miksa ili spleta prilagođenog ciljnom tržištu. Marketinški splet ili miks sastoji se od sljedećih marketinških instrumenata: proizvod, cijena, distribucija i promocija. Planiranje i primjena marketinških instrumenata, odnosno oblikovanje i primjena marketinškog spleta trebala bi uvijek, koli- 
ko je to moguće, biti usklađena s rezultatima marketinškog istraživanja.

Prvi korak marketinške strategije podrazumijeva analizu proizvoda, odnosno njegovih obilježja:

a) Kvalitete (zakonski propisi, boja, okus, miris, oblik, kemijski sastav, način proizvodnje i sl.).

b) Asortiman (raznovrsnost asortimana).

c) Pakiranje (ambalaža i grafički dizajn, praktično, svrsishodno, privlačno potrošačima, ovisi o ciljnim potrošačima i troškovima).

d) Etiketiranje (informativno i zanimljivo, istovremeno promocija proizvoda).

e) Označavanje (marka, oznaka zemljopisnog podrijetla, eko oznaka i dr.).

f) Prodajni servis (garancije i reklamacije).

g) Etiketiranje (informativno i zanimljivo, istovremeno promocija proizvoda).

Kanali prodaje ili distribucija instrument su marketinškog spleta koji podrazumijeva odluku o načinu prodaje proizvoda: izravno kupcima (izravna ili direktna prodaja) ili kroz razne prodajne kanale preko distributera (indirektni prodajni kanali). Gospodarstva koja se bave proizvodnjom vina najčešće ga prodaju u izravnoj prodaji bez posrednika kao i neizravnoj prodaji (prodaji trgovinskim organizacijama na malo, prodaji u ugostiteljskim objektima). Izravna prodaja često smanjuje trošak prodaje. Manji proizvođači često prakticiraju tu vrstu prodaje, primjerice prodajom u vlastitom podrumu. Prodaja se odvija dolaskom kupca, kušanjem vina, kupnjom i odlaskom. Za razliku od kupnje u indirektnim kanalima trgovini i ugostiteljstvu, povezano sa zadovoljstvom kupnje i dobivanjem informacija o gospodarstvu i njegovom razgledavanju. Kupac se može na licu mjesta upoznati s procesom proizvodnje i prerade vina. Dio kupljene robe kupci prilikom posjete sami preuzimaju i odvoze. Posebno je atraktivno ako u ponudi ima nečeg novog vezanog za vino i gospodarstvo. Uz ponudu vina pojavljuju se tradicionalni predmeti vezani za vino i gospodarstvo (čaše, otvarači za boce i sl.) s logotipom i dekorativnim elementima, slikom gospodarstva, tradicijske podrumske opreme i slično.

Promocija je prijenos informacija do kupca. Budući da uglavnom ne prodajete cijelom tržištu i promocija je usmjerena na određeni tržišni segment. Tako se i postupak obavještavanja kupaca razlikuje prema tome kome su usmjerene vaše informacije Pri promociji želimo potrošačima prenijeti informacije: o obilježjima proizvoda (kvaliteta, pakiranje, podrijetlo itd.); o posebnosti proizvoda (npr. pjenušavo vino); o sortimentu, cijenama i načinu dostave. Komunikacija s potrošačima podrazumijeva: reklamu, unaprjeđenje prodaje, osobnu prodaja i odnose s javnošću (Renko, 2009.). Promocija crnih vina treba se bazirati na promociji vina iz Srednje i Južne Dalmacije iz dva temeljna razloga: obavijestiti potencijalne kupce o kvaliteti domaćeg crnog vina u odnosu na uvozno vino te ih upoznati s mnogim pozitivnim učincima crnog 
vina na zdravlje. Ključna je i komunikacija s medijima te oglašavanje putem interneta i različitih sajmova, skupova, kataloga, itd. Isto tako bitno je uskladiti cijenu i kvalitetu vina tako da ona bude prihvatljiva ne samo turistima nego i lokalnom stanovništvu. Također još jedna jako bitna stavka izvoz je vina i pozicioniranje na samom tržištu jer danas imamo situaciju da se u Hrvatskoj više vina uveze nego izveze te tako ne iskorištavamo potencijal koji imamo.

Marketinški stručnjaci moraju istraživati i osluškuju potrebe tržišta kako bi na osnovi stečenih podataka mogli proizvod "upakirati" na najprivlačniji način za prodaju. Važna je i prilagodba aktualnim trendovima u svezi s proizvodom kojim se želi pridobiti ciljana skupina potrošača. Paralelno s time trebaju se pronaći i financijska sredstva (iz fondova poduzeća, bankovnih kredita itd.). Preporuča se i učinak sinergije (udruživanja) između dva ili više kvalitetnih proizvođača. U ovakav oblik strategijskog pothvata mogu se implementirati i prepoznatljivi elementi podneblja odakle vino dolazi, npr. slika na etiketi, ukrasni logotip, boce specifične izrade što povlači za sobom i posebnu strategiju promocijskih aktivnosti putem medija, pjesama, tiskovnog materijala, virtualnog dijela i slično. Marketinška strategija treba biti konkurentna u odnosu na druge proizvođače i kupcu prepoznatljiva putem promocije. Istraživanje pokazuje da su zbog velike količine polifenola najkvalitetnija vina u Srednjoj i Južnoj Dalmaciji, ali je to danas nažalost slabo iskorišteno putem promocije i marketinga. Iz tog razloga bi trebalo razviti strategiju kojim bi se vino poput "Zlatnog Plavca" s Hvara promoviralo kao kvalitetno, ali prije svega zdravo, zbog svog polifenolnog sastava te pozitivnih učinaka na zdravlje čovjeka.

U marketingu se treba poslužiti sljedećim pozitivnim osobinama crnog vina:

1. Crno vino kao ekstrakt grožđa, sadrži sve prirodne tvari koje se uspješno mogu izdvajati u čistom stanju.

2. Na kemijski sastav i svojstva crnog vina utječu podneblje u kojem se uzgaja grožđe, sorta vina, vrijeme berbe, proces prerade, skladištenje.

3. Berba grožđa se uglavnom obavlja ručno krajem kolovoza, početkom rujna. Što je grožđe tamnije i slađe, kakvoća i kvaliteta vina će biti bolja.

4. Nutricionostički gledano, crno vino je u suštini jako zdravo i što ima više polifenola to ima više pozitivnih učinaka na zdravlje čovjeka. Polifenolne supstance imaju razne biološke učinke te tako štite od nastanka ateroskleroze i koronarnih bolesti, a također imaju protuupalno, antikancerogeno i antimikrobno djelovanje.

Iz svega navedenoga, crna vina, zbog velike količine polifenola, treba iskoristiti te prodavati i promovirati kao autohtoni proizvod koji je zdrav te kao proizvod s prepoznatljivim geografskim porijeklom i certifikatom kvalitete. Također bi trebalo postojati što više vinskih cesta i podruma i na taj način upoznati kupce s kvalitetom 
vina. Jako bitna stvar je i marketing i promocija preko interneta, razno raznih događaja i manifestacija vezanih uz vino te ulazak i prodaja vina kao dio turističke ponude u ugostiteljskim objektima i trgovinama na veliko i malo. Konkurentnost također igra veliku ulogu u smislu dobrog pozicioniranja na tržište, usklađivanjem cijene i kvalitete proizvoda, stvaranjem branda, a samim time bi došlo i do povećanog izvoza što i je jedan od ciljeva. Jedna od velikih prednosti za proizvodnju crnog vina u Hrvatskoj podneblje je Dalmacije i Slavonije koji u svemu pogoduje dobroj kvaliteti grožđa te ga zato treba maksimalno iskoristiti, što dosada nažalost nije bio slučaj.

Još jedan dobar primjer dobrog marketinga vino je Vranac Pro Corde iz susjedne Crne Gore. Ova sorta, kako je 2008. godine i dokazano, autohtona je crnogorska, nastala najvjerojatnije $\mathrm{u}$ regiji Crmnice još $\mathrm{u}$ antičkim vremenima spontanim križanjem ili kao rezultat spontanih mutacija. Ime je, očigledno, dobila po crnoj (vranoj) boji zrele bobice. Ta bobica, kako se kasnije ispostavilo, u sebi skriva upravo ono za čim su tragali francuski naučnici: visok sadržaj proantocijanidina. Vranac Pro Corde ima izuzetno dobru promociju na svojoj mrežnoj stranici (http://plantaze.com/cg/\#/Vranac_ Pro_Corde). U katalogu proizvoda, uz opisane tehničke karakteristike vina, spominje se njegova ne samo prehrambena, već i farmakološka vrijednost. Proizvođači ističu kako su posebnim tehnološkim postupcima uspjeli proizvesti vino koje sadrži veliku koncentraciju proantocijanidina koji imaju blagotvorno djelovanje na ljudsko zdravlje a posebice na srce i krvne žile. Fotografija etikete toga vina prikazana je na slici 3.

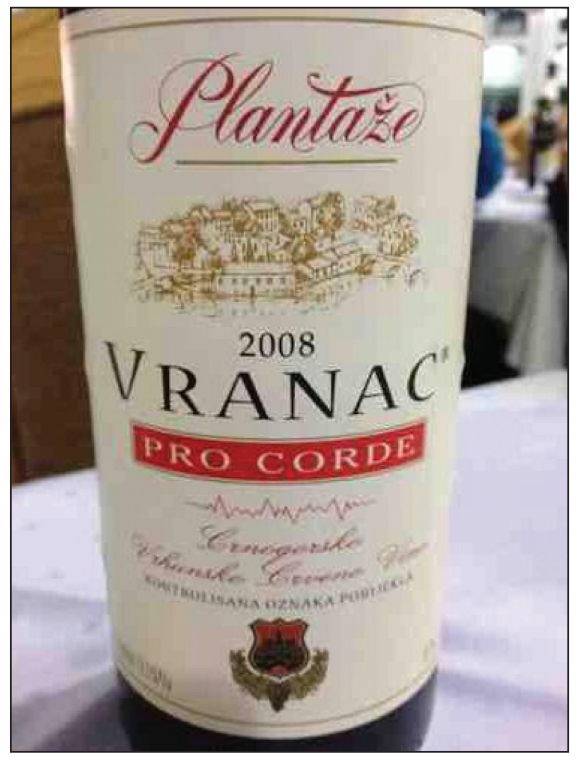

Slika 3. Fotografija etikete crnogorskog vina Vranac Pro Corde (http://plantaze.com/cg/\#/Vranac_Pro_Corde) 
Dobar primjer promocije vina koji se temelji na pozitivnom učinku na zdravlje ima vino Vinagra (Kutjevo d. d.). Vino je proizvedeno od sorte vinove loze refošk, sa slovenskog vinogorja Brič. Promocija tog vina temelji se na polifenolnom sastavu tog vina i rezultatima istraživanja antioksidacijske i vazodilatacijske aktivnosti. Svi detalji o vinu mogu se naći na internetskoj stranici: http://www.kutjevo.com/hr/izdvojeno/utjecaj-vina-vinagra-na-zdravlje.

\section{Zaključak}

Polifenoli su sastojci u vinu za koje su brojna znanstvena istraživanja dokazala da pozitivno utječu na ljudsko zdravlje. Prvenstveno djeluju preventivno na bolesti srca i krvnih žila. Polifenolne sastavnice vina zaslužne su za antikancerogeno, neuroprotektivno i antidijabetičko djelovanje. Na temelju toga, vino, posebice crno, može se smatrati funkcionalnom hranom koja ima i dokazano farmakološko djelovanje.

Hrvatska vina dokazano su visoke kvalitete i obiluju polifenolnim spojevima. Crna vina i vina iz Srednje i Južne Dalmacije imaju najveći sadržaj polifenola, što se pripisuje povoljnijim klimatskim uvjetima koje uvelike utječu na formiranje tih supstancija u grožđu tijekom zriobe. Međutim, neke sorte vina iz kontinentalne Hrvatske svojom kvalitetom ne zaostaju za dalmatinskim vinima. Naša vina moraju se istaknuti iz mase uvoznih vina koju su mahom jeftinija, ali ne nužno i slabije kvalitete od hrvatskih i privući kupca i u našoj zemlji, a posebice u inozemstvu.

Na temelju iznesenog možemo zaključiti da su hrvatska vina izvor zdravlja te se taj podatak može iskoristiti u marketinške svrhe. Marketing vina mora se temeljiti na promociji redovite, ali umjerene konzumacije vina.

\section{Literatura}

Al-Awwadi, N., Azay, J., Poucheret, P., Cassanas, G., Krosniak, M., Auger, C., Gasc, F., Rouanet, J.-M., Cros, G., Teissèdre, P.L. (2004), Red wine polyphenols alone or in association with ethanol prevent hypertension, cardiac hypertrophy, and production of reactive oxygen species in the insulin-resistant fructose-fed rat. J Agric Food Chem, 52, str. 1008-1016.

Bergqvist J., Dokoozlian N., Ebisuda N. (2001), Sunlight exposure and temperature effects on berry growth and composition of Cabernet Sauvignon and Grenache in the central San Joaquin Valley of California. Am J Enol Vitic, 52, str.1-7.

Budić-Leto I., Lovrić T. (2002), Content during fermentation and ageing of white wines Pošip and Rukatac. Food Technol Biotetechnolol, 40, 221-225.

Burns J., Gardner P. T., Matthews D., Duthie G. G., Lean M. E. J., Crozier A. (2001), 
Extraction of phenolics and changes in antioxidant activity of red wines during vinification. J Agric Food Chem, 49, str. 5797-5808.

Chuang C.C., McIntosh, M.K. (2011), Potential mechanisms by which polyphenol-rich grapes prevent obesity-mediated inflammation and metabolic diseases. Ann Rev Nutr, 31, str. 155-176.

Ćurko N., Kovačević Ganić K., Gracin L., Đapić M., Jourdes M., Teissedre P.-L. (2014), Characterization of seed and skin polyphenolic extracts of two red grape cultivars grown in Croatia and their sensory perception in a wine model medium. Food Chem, 145, str. 15-22.

Daglia M., Stauder M., Papetti A., Signoretto C., Giusto G., Canepari P., Pruzzo C., Gazzani G. (2010), Isolation of red wine components with anti-adhesion and anti-biofilm activity against Streptococcus mutans. Food Chem, 119, str. 1182-1188.

Delagado R., Martín P., del Álamo M., González M.-R. (2004), Changes in the phenolic composition of grape berries during ripening in relation to vineyard nitrogen and potassium fertilisation rates. J Sci Food Agric, 84, str. 623-630.

Erlund I. (2004), Review of the flavonoids quercetin, hesperetin, and naringenin. Dietary sources, bioactivities, bioavailability, and epidemiology. Nutr Res. 24, str. 851-874.

Fang F., Li J.-M., Pan Q.-H., Huang W.-D. (2007), Determination of red wine flavonoids by HPLC and effect of aging. Food Chem. 101, str. 428-433.

Gao Z.B., Hu G.-Y. (2005), Trans-resveratrol, a red wine ingredient, inhibits voltageactivated potassium currents in rat hippocampal neurons. Brain Res, 1056, str. 68-75.

Gehm B.D., Levenson A.S., Liu H., Lee E.-J., Amundsen B.M., Cushman M.; Jordan V.C., Jameson, J.L. (2004), Estrogenic effects of resveratrol in breast cancer cells expressing mutant and wild-type estrogen receptors: role of AF-1 and AF-2. J Steroid Biochem, 88, str. 223-234.

Gil M., Esteruelas M., Gonzáleu E., Kontoudakis N., Jiménez J., Fort, F., Canals J.M., Hermosín-Gutiérrez Zamora, F. (2013), Effect of two different treatments for reducing grape yield in Vitis vinifera cv Syrah on wine composition and quality: berry thinning versus cluster thinning. J Agric Food Chem, 61, str. 4968-4978.

Gutiérrez I.H., Sánchez-Palomo Lorenzo E., Espinosa A. V. (2005), Phenolic composition and magnitude of copigmentation in young and shortly aged red wines made from the cultivars, Cabernet Sauvignon, Cencibel, and Syrah. Food Chem, 92, str. 269-283.

He S., Sun C., Pan Y. (2008), Red wine polyphenols for cancer prevention. Int J Mol Sci. 9, str. 842-853. 
Herjavec S., Mirošević N., Fazinić M., Karoglan Kontić J., Peršurić Đ., Milat V., Gašparec-Skočić Lj., Ričković M., Bolić J. (2002), Hrvatska vina i vinari, Agmar, Zagreb.

Landrault N., Poucheret P., Ravel, P., Gasc F., Cros G., Teissedre P.-L. (2001), Antioxidant capacities and phenolics levels of French wines from different varieties and vintages. J Agric Food Chem, 49, str. 3341-3348.

Liu Z., Song Y., Zhang X., Liu Z., Zhang W., Mao W., Wang W., Ciu W., Zhang X., Jia X., Li N., Han C., Liu C. (2005), Effects of trans-resveratrol on hypertension-induces cardiac hypertrophy using the partially nephrectomized rat model. Clin Exp Pharmacol Physiol, 32, str. 1049-1054.

Katalinić V. (1997), High-performance liquid chrpmatographic determination of flavan fingerprints in plant extracts. J Chromatogr A, 775, str. 359-367.

Katalinić V., Ljubenkov I., Pezo I., Generalić I., Stričević O., Miloš M., Modun D., Boban M. (2008), Free resveratrol monomers in varietal red and white wines from Dalmatia (Croatia). Period biol, 110, str. 77-83.

Kallithraka S., E. Tsoutsouras, P. Tzourou, Lanaridis P. (2006), Principal phenolic compounds in Greek red wine. Food Chem, 99, str. 784-793.

King R.E, Kenta K.D., Bomser J.A. (2005), Resveratrol reduces oxidation and proliferation of human retinal pigment epithelial cells via extracellular signal-regulated kinase inhibition. Chem Bio Interact, 151, str.143-149.

Markham K.R. (1982), Techniques of Flavonoid Identification, Academic Press, London.

Martin S., González-Burgos E., Carretero M.E., Gómez-Serranillos M.P. (2011), Neuroprotective properties of Spanish red wine and its isolated polyphenols on astrocytes. Food Chem, 128, str. 40-48.

McDonald M.S., Hughes M., Burns J., Lean M.E.J., Matthews D., Crozier A. (1998), Survey of the free and conjugated myricetin and quercetin content of red wines of different geographical origins. J Agric Food Chem, 46, str. 368-375.

Mateus N., Proença S., Ribeiro P., Machado J.M., De Freitas V. (2001), Grape and wine polyphenolic composition of red Vitis vinifera varieties concerning vineyard altitude. Cienc Technol Alliment, 3, str. 102-110.

Monteiro, R., Faria, A., Mateus, N., Calhau, C., Azevedo, I. (2008), Red wine interferes with oestrogen signalling in rat hippocampus. J Steroid Biochem Mol Biol, 111, str. 74-79.

Mudnic I., Modun D., Rastija V., Vukovic J., Brizic I., Katalinic V., Kozina B., MedicSaric M., Boban M. (2010), Antioxidative and vasodilatory effects of phenolic acids in wine. Food Chem, 119, str. 1205-1210.

Nicolosi E., Continella A., Gentiloe A., Cicala A., Ferlito F. (2012), Influence of early leaf removal on autochthonous and international grapevines in Sicily. Sci Horticult, 146, str. 1-6. 
Ou H.-C., Chou F.-P., Sheen H.-M., Lin T.-M., Yang C.-H., Sheu H.-H. (2006), Resveratrol, a polyphenolic compound in red wine, protects against oxidized LDL-induced cytotoxicity in endothelial cells. Clin Chim Acta, 364, str. 196-204.

Panico A.M., Cardile V., Avondo S., Garufi F., Gentile B., Puglia C., Bonina F., Santagati N.A., Ronsisvalle G. (2006), The in vitro effect of a lyophilized extract of wine obtained from jacquez grapes on human chondrocytes. Phytomedicine, 13, 522-526.

Rastija V. (2011), An overview of innovations in analysis and beneficial health effects of wine polyphenols. Mini Rev Med Chem, 11, str. 1-12.

Rastija V., Srečnik G., Medić-Šarić M. (2009), Polyphenolic composition of Croatian wines with different geographical origins. Food Chem, 115, str. 54-60.

Renaud S.C., de Lorgeril M. (1992), Wine, alcohol, platelets, and the French paradox for coronary heart disease. Lancet, 339, str. 1523-1526.

Renko N. (2009), Strategije marketinga, Naklada Ljevak, Zagreb.

Revilla I., González-SanJosé M. L., (2003), Compositional changes during the storage of red wines treated with pectolytic enzymes: low molecular-weight phenols and flavan-3-ol derivative levels. Food Chem, 80, str. 205-214.

Russo A., Palumbo M., Aliano C., Lempereur L., Scoto G., Renis A. (2003), Red wine micronutrients as protective agents in Alzheimer-like induced insult. Life Sci, 72, str. 2369-2379.

Soleas G.J., Grass L., Josephy P.D., Goldberg D.M., Diamandis E.P. (2002), A comparison of the anticarcinogenic properties of four red wine polyphenols. Clin Biochem, 35, str. 119-124.

Szewczuk L.M., Penning T.M. (2004), Mechanism-based inactivation of COX-1 by red wine $m$-hydroquinones: A Structure-activity relationship study. J Nat Prod 67, str. 1777-1782.

Šeruga M., Novak I., Jakobek L. (2011), Determination of polyphenols content and antioxidant activity of some red wines by differential pulse voltammetry, HPLC and spectrophotometric methods. Food Chem, 124, str. 1208-1216.

Weston L.A. (2000), Wine Industry Workshop Proceedings, New York State Agricultural Experiment Station Dept. of Food Science and Technology, Geneva, str. 6-14.

Zafrilla P., Morillas J., Mulero J., Cayuela J. M., Martínez-Cachá A., Pardo F., Nicolás J. M. L. (2003), Changes during storage in conventional and ecological wine: phenolic content and antioxidant activity. J Agric Food Chem, 51, str. 4694-4700. 


\section{Using Knowledge of the Polyphenolic Profile of Croatian Wines for Marketing Purposes}

\section{Summary}

Regular moderate wine consumption has been associated with numerous health benefits. These effects are associated with polyphenolic compounds found in wine that have the strongest influence on cardiovascular diseases. Polyphenols also exhibit anti-cancerogenic, neuroprotective, and anti-diabetic effects. Hence, wine, and especially red wine, may be considered as functional food with confirmed pharmacological effects. Croatia abounds with vineyards and high-quality wine, but these facts are insufficiently used in marketing.

Red wine sorts from Central and South Dalmatia have the highest polyphenolic content that is attributed to favourable climatic conditions, which greatly determine the formation of these compounds during the ripening of grapes. Several wine sorts from continental Croatia, owing to their quality, are, however, not at all inferior to Dalmatian wine. Hence, our wine should be propounded from the bulk of cheap and lower-quality imported wine, as well as attract customers both at home and abroad. Given facts should be maximally used in the strategy of the selling, distribution, promotion and marketing of Croatian wine.

Keywords: polyphenols; Croatian wine; functional food; marketing.

Doc. dr. sc. Vesna Rastija

Poljoprivredni fakultet Sveučilišta J. J. Strossmayera u Osijeku

Kralja Petra Svačića 1d, 31000 Osijek

vrastija@pfos.hr 